\title{
Role of Dihydropyrimidine Dehydrogenase in the Uridine Nucleotide Metabolism in the Rat Liver
}

\author{
Shigeko Fujimoto, Mariko Kikugawa, Masae Kaneko, \\ and Nanaya TAMAKI \\ Faculty of Nutrition, Kobe-Gakuin University, \\ Nishi-ku, Kobe 651-21, Japan
}

(Received August 29, 1991)

\begin{abstract}
Summary The activity of dihydropyrimidine dehydrogenase, which is the rate-limiting enzyme in the catabolism of pyrimidine, in livers of 5day-old rats increased $48 \mathrm{~h}$ after glucocorticoid injection. The increase in the activity of dihydropyrimidine dehydrogenase by glucocorticoid administration and by aging did not decrease the uridine, uracil and $\Sigma$ UMP (the sum of acid-soluble uracil $5^{\prime}$-nucleotides) pool in liver. The increase of liver uracil by a uridine diet not increase dihydropyrimidine dehydrogenase activity. The increase of liver uracil did not increase dihydropyrimidine dehydrogenase activity. However, dihydropyrimidine dehydrogenase activity which increased after glucocorticoid treatment increased the pyrimidine-degradation rate in rat livers and hepatocytes. Pyrimidine catabolism pathway in liver may play an important role in degradation of dietary pyrimidines and pyrimidines which are administered in the form of medicines as 5-fluorouridine.
\end{abstract}

Key Words dihydropyrimidine dehydrogenase, uridine nucleotide pool, uridine, pyrimidine metabolism, 5-fluorouridine

Dihydropyrimidine dehydrogenase is the rate-limiting enzyme in the pyrimidine catabolic pathway (1). The enzyme activities in the degradation pathway of pyrimidine increase during postnatal differentiation (2), and those in hepatomas and regenerating rat liver decrease in parallel with the growth rate $(2,3)$. It seems that dihydropyrimidine dehydrogenase activity decreases when cells require many pyrimidine bases during growth. Dihydropyrimidine dehydrogenase degrades 5fluorouracil, an antitumor drug, and the level of this enzyme affects the antitumor efficacy of 5-fluorouracil (4).

Carbamoyl phosphate synthase, which is the first enzyme in the de novo pyrimidine synthetic pathway, is regulated by product inhibition by UTP (5). Uridine kinase, which is an enzyme in the salvage pathway and which forms UMP from uridine, is also inhibited by UTP and CTP (6). However, the role of the 
pyrimidine catabolic pathway in the regulation of the pyrimidine pool in the liver has not been clarified. We found that the decrease in liver dihydropyrimidine dehydrogenase activity in rats fed on a vitamin $B_{2}$-deficient diet had no effect on uridine, uracil and $\Sigma$ UMP pools in liver (7). In the present experiments, we showed the participation of dihydropyrimidine dehydrogenase activity on uridine, uracil and $\Sigma$ UMP levels and the uracil-degradation rate, and studied the effect of variations in the pools on dihydropyrimidine dehydrogenase activity.

\section{MATERIALS AND METHODS}

Chemicals and animals. $\left[6-{ }^{3} \mathrm{H}\right]$ Uracil, $\left[6-{ }^{3} \mathrm{H}\right]$ uridine and $\beta-\left[2-{ }^{14} \mathrm{C}\right]$ alanine were obtained from New England Nuclear, U.S.A. William's medium E and other materials used for cell isolation and culture were the products of Flow Laboratories Inc., U.S.A. Animal feeds were obtained from Oriental Yeast Ltd., Tokyo. All other chemicals were purchased from Nacalai Tesque, Kyoto. Rats were obtained from Japan SLC Inc. and 5-day-old rats from the same mother were used as the control.

Enzyme assays. Rat livers were excised between 9:00-11:00 a.m. and were homogenized in $10 \mathrm{~mm}$ potassium phosphate buffer, $\mathrm{pH} 7.4,5 \mathrm{~mm}$ 2-mercaptoethanol, $2.5 \mathrm{mM} \mathrm{MgCl}$ (buffer A), and the enzyme activities were assayed. Dihydropyrimidine dehydrogenase activity was determined by measuring uracil reductase activity at $37^{\circ} \mathrm{C}$ for 20 min according to the method of Naguib et al. (8). The standard assay mixture contained $50 \mathrm{~mm}$ potassium phosphate buffer, $\mathrm{pH} 7.4$, $50 \mathrm{~mm}$ 2-mercaptoethanol, $1 \mathrm{mM}$ NADPH, $20 \mu \mathrm{M}\left[6{ }^{3} \mathrm{H}\right]$ uracil $(1.48 \mathrm{MBq} / \mu \mathrm{mol})$ and $50 \mu 1$ enzyme in a final volume of $0.5 \mathrm{ml}$. Since the level of NADPH and uracil from livers was $1 / 200$ the $\left[6-{ }^{3} \mathrm{H}\right]$ uracil and NADPH which were added to the assay mixture, the substrates in liver did not affect the enzyme activity. In the measurement of the enzyme activity in rats fed a uridine diet, the liver homogenate was centrifuged, fractionated using 30-50\% $\left(\mathrm{NH}_{4}\right)_{2} \mathrm{SO}_{4}$ and dialyzed against buffer $\mathrm{A}$ to remove the uridine and uracil in liver. Aminobutyrate aminotransferase and D- $\beta$-aminoisobutyrate-pyruvate aminotransferase activities were assayed as previously described (9). Tyrosine aminotransferase activity was determined by the method of Granner and Tomkins (10).

Uracil, uridine and $\Sigma U M P$ pool determination. Freezed-clamped liver tissue was homogenized in 5 vols. of $0.6 \mathrm{M}$ perchloric acid. After centrifugation the supernatant was neutralized and added to an assay mixture containing $0.2 \mathrm{M}$ Tris- $\mathrm{HCl}, \mathrm{pH} 8.9,0.5 \mathrm{~mm} \mathrm{MgCl}_{2}$ and $20 \mu \mathrm{g}$ snake venom phosphodiesterase (Boehringer). After standing at $37^{\circ} \mathrm{C}$ for $60 \mathrm{~min}$ the reaction was stopped by boiling for $5 \mathrm{~min}$. After treatment with Sep Pak C18 (Waters) and concentration, uracil, uridine and $\Sigma$ UMP were separated by HPLC (Waters model M-600) using a linear methanol gradient from $50 \mathrm{~mm}$ potassium phosphate buffer, $\mathrm{pH} 5.6$, to $20 \%$ methanol for $40 \mathrm{~min}$ on a reverse-phase C18 analytical column (Waters, $5 \mu, 0.39 \times$ $15 \mathrm{~cm}$ ) and detected at $254 \mathrm{~nm}$. Serum was mixed with 0.1 vol. $4 \mathrm{M}$ perchloric acid 
and after centrifugation the supernatant was neutralized with $\mathrm{KOH}$. After brief centrifugation the supernatant was treated by the same method as the liver.

Steroid hormone administration. Hydrocortisone acetate, testosterone or estrone $(1.5 \mathrm{mg} / 100 \mathrm{~g}$ body weight) was injected into 5-day-old rats subcutaneously. To the rats fed on uridine diet, hydrocortisone acetate $(5.0 \mathrm{mg} / 100 \mathrm{~g}$ body weight $)$ was injected subcutaneously. Hormones were emulsified to a concentration of 1 $\mathrm{mg} / \mathrm{ml}$ in $1 \%$ carboxymethyl cellulose in $0.9 \% \mathrm{NaCl}$. Control rats were injected $1 \%$ carboxymethyl cellulose in $0.9 \% \mathrm{NaCl}$.

Composition of uridine diet. Uridine diet contained $20 \%$ casein, $18 \%$ sucrose, $35 \%$ corn starch, $6 \%$ soybean oil, $6 \%$ salt mixture, $2 \%$ vitamin mixture, $8 \%$ cellulose powder and 5\% uridine by weight. Mineral mixture and vitamin mixture were obtained from Oriental Yeast Ltd., Tokyo. Minerals were (in $\mathrm{g} / \mathrm{kg}$ of diet): $\mathrm{CaHPO}_{4} \cdot 2 \mathrm{H}_{2} \mathrm{O}$ 8.736; $\mathrm{KH}_{2} \mathrm{PO}_{4}$ 15.432; $\mathrm{NaH}_{2} \mathrm{PO}_{4}$ 5.610; $\mathrm{NaCl}$ 2.796; Ca-lactate 21.054; Fe-citrate 1.908; $\mathrm{MgSO}_{4} 4.302 ; \mathrm{ZnCO}_{3} 0.066 ; \mathrm{MnSO}_{4} \cdot 4 \sim 6 \mathrm{H}_{2} \mathrm{O} 0.072 ;$ $\mathrm{CuSO}_{4} \cdot 5 \mathrm{H}_{2} \mathrm{O} 0.018$; $\mathrm{KI} 0.006$. Vitamins were (in $\mathrm{mg} / \mathrm{kg}$ of diet): retinyl acetate 3.6; cholecalciferol 0.05 , rac- $\alpha$-tocopheryl acetate 100; menadione 104; thiamin hydrochloride 24; riboflavin 80; pyridoxine hydrochloride 16 ; cyanocobalamin 0.01 ; ascorbic acid 600; D-biotin 0.4 ; folic acid 4; calcium pantothenate $100 ; p$ aminobenzoic acid 100; niacin 120; choline chloride 4,000. Control diet contained an additional $5 \%$ corn starch instead of $5 \%$ uridine.

Degradation of 5-fluorouridine. Hydrocortisone acetate was injected as stated above and 5-fluorouridine $(20 \mathrm{mg} / 100 \mathrm{~g}$ body weight $)$ was injected intraperitoneally $48 \mathrm{~h}$ after the injection. 5-Fluorouridine and 5-fluorouracil were determined by the same method as for uridine.

Primary rat hepatocytes culture and $\left[6-{ }^{3} \mathrm{H}\right]$ uridine degradation in hepatocytes. Hepatocytes were isolated from 5-day-old rat liver slices by collagenase digestion (11). The cells were suspended at a density of $10^{6}$ cells $/ \mathrm{ml}$ in William's medium E containing 5\% calf serum and cultured at $2 \times 10^{5}$ cells $/ \mathrm{cm}^{2}$ in Falcon plastic dishes $\left(6 \mathrm{~cm}\right.$ diameter) at $37^{\circ} \mathrm{C}$ under $5 \% \mathrm{CO}_{2}$ in air. After $12 \mathrm{~h}$ the medium was replaced by fresh medium to which test samples were added. For enzyme activity assays, hepatocytes were washed with ice-cold phosphate-buffered saline $(0.137 \mathrm{M} \mathrm{NaCl}$, $2.68 \mathrm{mM} \mathrm{KCl}, 8.09 \mathrm{mM} \mathrm{Na}_{2} \mathrm{HPO}_{4} \cdot 12 \mathrm{H}_{2} \mathrm{O}$ and $1.17 \mathrm{mM} \mathrm{K \textrm {K } _ { 2 }} \mathrm{PO}_{4}$ ), harvested using a rubber policeman and then disrupted by 3 cycles of freeze-thawing. The enzyme activities in the cell suspension were measured as described above. For the uridine degradation experiment, $24 \mathrm{~h}$ after hydrocortisone acetate or control addition the medium was changed to $3 \mathrm{ml}$ fresh medium which did not contain hydrocortisone. After standing for $2 \mathrm{~h}, 200 \mu \mathrm{l}\left[6-{ }^{3} \mathrm{H}\right]$ uridine $(0.185 \mathrm{MBq} / 60 \mathrm{nmol}$ per $\mathrm{ml})$ was added to the medium. The cells were washed with ice-cold phosphate-buffered saline 3 times and treated with $0.4 \mathrm{M}$ perchloric acid $30 \mathrm{~s}, 3 \mathrm{~min}$ and $30 \mathrm{~min}$ after the $\left[6-{ }^{3} \mathrm{H}\right]$ uridine addition. The cell supernatant was neutralized with $4 \mathrm{M} \mathrm{KOH}$ and spotted on a cellulose TLC plate (solvent : water). The radioactivity of each spot or media was counted using a Packard liquid scintillation spectrometer. 


\section{RESULTS}

Effect of glucocorticoid on dihydropyrimidine dehydrogenase activity in livers of 5day-old rats

Figure 1 shows the effects of hydrocortisone on dihydrouracil dehydrogenase activity in 5-day-old rat liver. A significant increase in dihydropyrimidine dehydrogenase activity was seen $48 \mathrm{~h}$ after glucocorticoid administration while there was no increase in the activity at 6 and $24 \mathrm{~h}$ after administration. Aminobutyrate aminotransferase, which degrades $\beta$-alanine formed via uracil, also increased in activity $48 \mathrm{~h}$ after glucocorticoid injection. However, D- $\beta$-aminoisobutyratepyruvate aminotransferase, which degrades $\beta$-alanine with pyruvate, was not affected by glucocorticoid administration (data not shown). Tyrosine aminotransferase, which is known to be induced by glucocorticoids, increased 6 and $24 \mathrm{~h}$ after glucocorticoid injection and returned to the control level after $48 \mathrm{~h}$. Testosterone and estrone did not affect dihydropyrimidine dehydrogenase activity. To understand the direct effects of hormones on the liver we studied them in primary cultured hepatocytes. The results are shown in Table 1. Dihydropyrimidine dehydrogenase and aminobutyrate aminotransferase increased to 4.2- and 5.2-fold, respectively, after glucocorticoid treatment in primary cultured hepatocytes which were prepared from livers of 5-day-old rats. However, the addition of a high level of glucagon and insulin had no effect on the activities of both enzymes.

\section{Uracil, uridine and $\Sigma U M P$ pool in rat liver}

As shown in Table 2, an increase in dihydropyrimidine dehydrogenase in liver following glucocorticoid administration did not decrease uracil, uridine and $\Sigma$ UMP

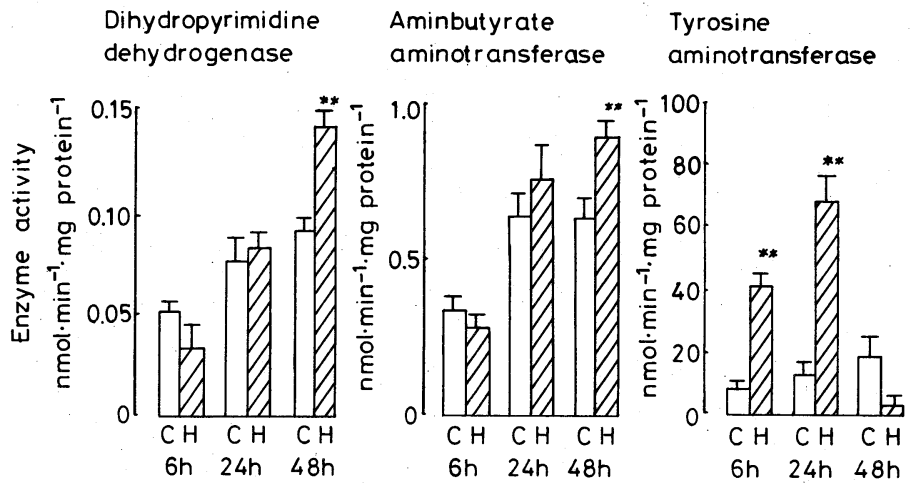

Fig. 1. Increase in dihydropyrimidine dehydrogenase activity by glucocorticoid treatment in 5-day-old rat liver. Enzyme activities of rat livers were assayed 6, 24 and $48 \mathrm{~h}$ after hydrocortisone injection. $*^{* *} p<0.01$ : significantly different from control. Each value is the mean $\pm \mathrm{SE}$ from 3 rats. $\mathrm{C}$, control; $\mathrm{H}$, hydrocortisone administration. 
Table 1. Effect of various hormones on dihydropyrimidine dehydrogenase activity in cultured hepatocytes from 5-day-old rat.

\begin{tabular}{|c|c|c|c|c|}
\hline Treatments & $\begin{array}{c}\text { Hormone } \\
\text { concentration }\end{array}$ & $\begin{array}{l}\text { Dihydropyrimidine } \\
\text { dehydrogenase }\end{array}$ & $\begin{array}{l}\text { Aminobutyrate } \\
\text { aminotransferase }\end{array}$ & $\begin{array}{c}\text { Tyrosine } \\
\text { aminotransferase }\end{array}$ \\
\hline & $\mu \mathbf{M}$ & \multicolumn{3}{|c|}{$\mathrm{nmol} \cdot \min ^{-1} \cdot \mathrm{mg}$ protein ${ }^{-1}$} \\
\hline Control & - & $0.029 \pm 0.0021$ & $0.013 \pm 0.0013$ & $0.91 \pm 0.12$ \\
\hline Hydrocortisone & 1 & $0.121 \pm 0.0026^{* *}$ & $0.067 \pm 0.0066^{* *}$ & $23.43 \pm 3.17^{* *}$ \\
\hline Glucagon & 10 & $0.025 \pm 0.0135$ & $0.016 \pm 0.0009$ & $0.72 \pm 0.43$ \\
\hline Insulin & 10 & $0.019 \pm 0.0084$ & $0.021 \pm 0.0034$ & $2.07 \pm 0.40^{*}$ \\
\hline
\end{tabular}

Hepatocytes were cultured for $12 \mathrm{~h}$ and the medium was then changed to fresh William's medium E containing 5\% calf serum supplemented as indicated. Enzyme activities were measured after culture for $24 \mathrm{~h}$. Each value is the mean $\pm \mathrm{SE}(n=3)$. $*_{p}<0.05,{ }^{* *} p<0.01$ compared to control.

Table 2. Uracil, uridine and $\Sigma$ UMP pool in glucocorticoid-treated 5-day-old rat liver.

\begin{tabular}{cccc}
\hline Treatment & Uracil & Uridine & $\Sigma$ UMP \\
\hline & & $\mathrm{nmol} \cdot \mathrm{g} \mathrm{liver}^{-1}$ & \\
24h Control & $6.46 \pm 0.87$ & $10.8 \pm 1.04$ & $1,109 \pm 172.7$ \\
Hydrocortisone & $7.08 \pm 0.17$ & $12.6 \pm 0.79$ & $897 \pm 143.5$ \\
48 h Control & $7.74 \pm 1.72$ & $10.5 \pm 2.14$ & $900 \pm 191.0$ \\
Hydrocortisone & $8.96 \pm 1.87$ & $13.1 \pm 0.33$ & $705 \pm 29.1$ \\
\hline
\end{tabular}

Hydrocortisone acetate $(1.5 \mathrm{mg} / 100 \mathrm{~g}$ body weight) was injected into 5-day-old rats. Uracil, uridine and $\Sigma$ UMP were measured 24 or $48 \mathrm{~h}$ after injection. Each value is the mean $\pm \operatorname{SE}(n=3)$.

Table 3. Effect of age on uracil, uridine and $\Sigma$ UMP pool in rat liver.

\begin{tabular}{|c|c|c|c|c|c|}
\hline \multirow{2}{*}{ Age } & \multirow{2}{*}{$\begin{array}{c}\text { Number } \\
\text { of rats }\end{array}$} & \multirow{2}{*}{$\begin{array}{c}\text { Serum } \\
\text { Uridine }\end{array}$} & \multicolumn{3}{|c|}{ Liver } \\
\hline & & & Uracil & Uridine & $\Sigma \mathrm{UMP}$ \\
\hline & & $\mathrm{nmol} \cdot \mathrm{ml}^{-1}$ & & $\mathrm{nmol} \cdot \mathrm{g}$ liver $^{-1}$ & \\
\hline 5-Day-old & 6 & $4.21 \pm 1.95$ & $7.1 \pm 0.91$ & $10.7 \pm 1.1$ & $1,110 \pm 172.7$ \\
\hline 6-Week-old & 6 & $4.03 \pm 1.03$ & $15.5 \pm 0.45^{* *}$ & $14.6 \pm 2.9$ & $955 \pm 68.1$ \\
\hline 3-Month-old & 13 & $2.58 \pm 0.53$ & $10.3 \pm 0.74^{*,++}$ & $17.9 \pm 3.9$ & $804 \pm 80.0$ \\
\hline
\end{tabular}

Each value is the mean \pm SE. ${ }^{* *} p<0.01, *_{p}<0.05$ compared to 5 -day-old rats. ${ }^{++} p<0.01$ compared to 6-week-old rats.

pool. Dihydropyrimidine dehydrogenase activity increased during postnatal differentiation (2) but it did not affect the pool in livers from 5-day-old, 6-week-old and 3-month-old rats by one-way analysis of variance (Table 3). However, the uracil content in rat livers fed uridine-rich diet increased 64-fold of that in control rat livers (Table 4). This increase followed the increase of $\Sigma$ UMP, but in uracil content had no effect on dihydropyrimidine dehydrogenase activity. When glu- 
Table 4. Effect of uridine diet on uracil, uridine and $\Sigma$ UMP pool in rat liver.

\begin{tabular}{lcccc}
\hline \multicolumn{1}{c}{ Treatments } & Uracil & Uridine & $\Sigma$ UMP & $\begin{array}{c}\text { Dihydropyrimidine } \\
\text { dehydrogenase }\end{array}$ \\
\hline & & $\mathrm{nmol}^{\prime} \mathrm{g} \mathrm{liver}^{-1}$ & & $\mathrm{nmol} \cdot \mathrm{min}^{-1} \cdot \mathrm{mg} \mathrm{protein}^{-1}$ \\
Control diet & $14.3 \pm 1.73$ & $19.6 \pm 3.08$ & $870 \pm 66.7$ & $0.438 \pm 0.034$ \\
Uridine diet & $917 \pm 120^{* *}$ & $26.7 \pm 7.65$ & $1,522 \pm 169.0^{*}$ & $0.439 \pm 0.022$ \\
$\begin{array}{l}\text { Uridine diet } \\
\text { +hydrocortisone }\end{array}$ & $351 \pm 106^{* *++}$ & $21.3 \pm 2.21$ & $970 \pm 125.0$ & $0.574 \pm 0.029^{*}$ \\
\hline
\end{tabular}

Control or uridine diet was given to 4-week-old rats for 1 week. Hydrocortisone acetate $(5 \mathrm{mg} / 100 \mathrm{~g}$ body weight $)$ was injected subcutaneously. Each value is the mean \pm SE $(n=3) .{ }^{* *} p<0.01,{ }^{*} p<0.05$ compared to control. ${ }^{+} p<0.05$ compared to uridine diet group.

cocorticoid was injected $48 \mathrm{~h}$ before the livers of rats fed uridine diet were excised, the uracil content in glucocorticoid-treated rat livers significantly decreased comparing with the level in rats fed on uridine diet alone, but the increment of $\Sigma \mathrm{UMP}$ was reduced. There is no significant difference in food consumption between the group on uridine-diet alone and the group on uridine-diet + glucocorticoid. This result shows that the increase in dihydropyrimidine dehydrogenase activity increased uracil degradation in vivo. The content of $\Sigma \mathrm{UMP}$ in rat livers of the uridine diet group increased by only 2 -fold that of control rat livers, and uridine did not increase whereas uracil increased 64-fold. Uridine is metabolized to uracil in the serosal cells after uridine crosses the mucosal cells of the small intestine (12). Thereafter, uracil is transported into the liver and may accumulate in it under these conditions.

Effect of dihydropyrimidine dehydrogenase on uridine degradation in rat hepatocytes Since about $4 \mu \mathrm{M}$ uridine existed in serum (Table 3 ), $4 \mu \mathrm{M}\left[6-{ }^{3} \mathrm{H}\right]$ uridine was added to medium and $\left[6-{ }^{3} \mathrm{H}\right]$ uridine uptake and degradation were studied using cultured hepatocytes. The results are shown in Table 5. The radioactivity in the medium was constant $0.5,3$ and $30 \mathrm{~min}$ after $\left[6-{ }^{3} \mathrm{H}\right]$ uridine addition. However, it was found that the $\left[6-{ }^{3} \mathrm{H}\right]$ uridine content in the medium were analyzed by TLC. When comparing the group in which dihydropyrimidine dehydrogenase activity was increased following glucocorticoid therapy (glucocorticoid group) with the control group, the $\left[6-{ }^{3} \mathrm{H}\right]$ uridine in the glucocorticoid-group medium was lower than that of control group. The $\left[6-{ }^{3} \mathrm{H}\right]$ uridine degradation rate was calculated by the amount of $\left[6-{ }^{3} \mathrm{H}\right]$ uridine which was consumed in the medium. The values for the control group and glucocorticoid group were 0.080 and $0.124 \mathrm{nmol} \cdot \mathrm{min}^{-1} \cdot \mathrm{mg}$ protein $^{-1}$, respectively. This shows that an increase in dihydropyrimidine dehydrogenase activity increases the uridine-degradation rate. Furthermore, it was thought that cells incorporated $\left[6-{ }^{3} \mathrm{H}\right]$ uridine, degraded it and excreted the degradation products, e.g. ${ }^{3} \mathrm{H}_{2} \mathrm{O}$ through the cell membrane. Collected cells were 
Table 5. ${ }^{3} \mathrm{H}$-Uridine degradation in cultured hepatocytes from 5-day-old rats.

\begin{tabular}{|c|c|c|c|c|c|}
\hline \multirow{2}{*}{$\begin{array}{l}\text { Incubation } \\
\text { time with } \\
{\left[6-{ }^{3} \mathrm{H}\right] \text { uridine }}\end{array}$} & \multirow{2}{*}{ Medium } & \multirow{2}{*}{$\begin{array}{c}\begin{array}{c}\text { Cell (acid } \\
\text { insoluble) }\end{array} \\
\text { Total }\end{array}$} & \multicolumn{3}{|c|}{ Cell (acid soluble) } \\
\hline & & & Total & Uridine & Uracil \\
\hline & $\operatorname{dpm}\left(\times 10^{-3}\right)$ & $\begin{array}{l}\mathrm{m}\left(\times 10^{-3}\right) / \mathrm{mg} \\
\text { cell protein }\end{array}$ & $\operatorname{dpm}(\times 1$ & )$\left.^{-3}\right) / \mathrm{mg}$ cel & protein \\
\hline \multicolumn{6}{|l|}{$0.5 \mathrm{~min}$} \\
\hline Control & $571 \pm 41$ & $1.2 \pm 0.3$ & $12.2 \pm 1.3$ & $5.4 \pm 0.6$ & $2.5 \pm 0.7$ \\
\hline Hydrocortisone & $642 \pm 70$ & $1.4 \pm 0.1$ & $16.2 \pm 0.5^{*}$ & $6.6 \pm 0.7$ & $4.6 \pm 0.2$ \\
\hline \multicolumn{6}{|l|}{$3 \mathrm{~min}$} \\
\hline Control & $534 \pm 42$ & $1.6 \pm 0.2$ & $73.1 \pm 4.5$ & $16.7 \pm 2.0$ & $32.6 \pm 3.0$ \\
\hline Hydrocortisone & $587 \pm 43$ & $3.2 \pm 0.5^{*}$ & $92.1 \pm 7.2$ & $18.4 \pm 2.7$ & $40.9 \pm 3.1$ \\
\hline \multicolumn{6}{|l|}{$30 \mathrm{~min}$} \\
\hline Control & $383 \pm 28$ & $1.1 \pm 0.1$ & $74.0 \pm 3.1$ & $11.7 \pm 1.7$ & $25.3 \pm 2.2$ \\
\hline Hydrocortisone & $260 \pm 17^{*}$ & $1.4 \pm 0.1$ & $74.1 \pm 3.4$ & $6.7 \pm 0.8$ & $22.4 \pm 1.7$ \\
\hline
\end{tabular}

Each value is the mean $\pm \operatorname{SE}(n=3) . *_{p}<0.05$ compared to control.
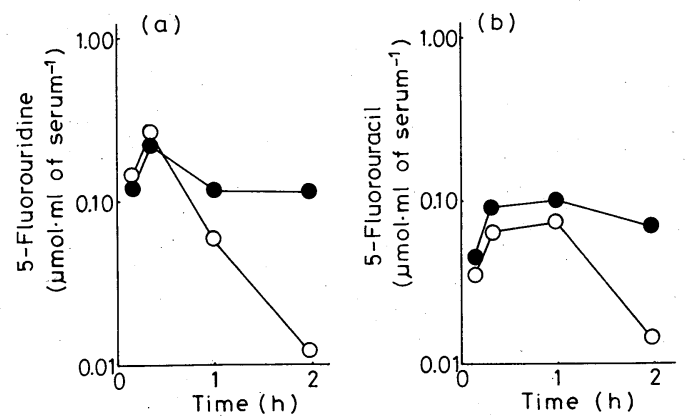

Fig. 2. Effect of glucocorticoid administration on disappearance of 5-fluorouridine in 5-day-old rat. 5-Fluorouridine $(20 \mathrm{mg} / 100 \mathrm{~g}$ body weight) was administered intraperitoneally $48 \mathrm{~h}$ after glucocorticoid or control treatment. Pooled serum of the same volume each from five rats was used as the sample preparation. (a) 5fluorouridine, (b) 5-fluorouracil. ๑, control; $\bigcirc$, glucocorticoid administration.

treated with perchloric acid, centrifuged and separated into supernatant and precipitate (RNA). Incorporation of $\left[6-{ }^{3} \mathrm{H}\right]$ uridine into RNA was very low because the radioactivity in the cell precipitate was low at about 10-20\% of that in the cell supernatant. The radioactivity in cell supernatant was constant from 3 to $30 \mathrm{~min}$ and there was no different between the glucocorticoid group and control group. The contents of $\left[6-{ }^{3} \mathrm{H}\right]$ uridine and $\left[6-{ }^{3} \mathrm{H}\right]$ uracil in cell supernatant of the glucocorticoid group were similar to those of the control group. 
Effect of glucocorticoid administration on degradation rate of 5-fluorouridine in 5day-old rat

5-Fluorouridine was injected intraperitoneally $48 \mathrm{~h}$ after glucocorticoid or $1 \%$ carboxymethyl cellulose administration. As shown in Fig. 2, the rate of disappearance of 5-fluorouridine from serum of the glucocorticoid group was faster than that of the control group. In 5-day-old rats, the dihydropyrimidine dehydrogenase activity in glucocorticoid-treated rat liver and that in control rat liver were 27.3士 1.36 and $18.2 \pm 0.84 \mathrm{nmol} \cdot \mathrm{min}^{-1} \cdot \mathrm{g}$ wet tissue ${ }^{-1}$, respectively, and showed a significant difference from each other.

\section{DISCUSSION}

Uracil is degraded to $\mathrm{CO}_{2}$ and $\mathrm{H}_{2} \mathrm{O}$ mainly in liver. Dihydrouracil dehydrogenase, the rate-limiting enzyme, in liver of 5-day-old rats increased by glucocorticoid administration. However, $\Sigma$ UMP pool did not change when dihydropyrimidine dehydrogenase activity increased following glucocorticoid treatment (Table 2 ) and by aging (Table 3). An increase of uracil content in the liver during uridine diet administration did not increase the enzyme activity (Table 4). In a previous paper (7), we reported that dihydropyrimidine dehydrogenase activity was not affected by pyrimidine nucleotides or their degradation products in vitro. These results differed in as much as the activities of the enzymes of the de novo pathway and the enzymes of the salvage pathway are regulated at the nucleotide level $(5,6)$. It was thought that the de novo pathway and the salvage pathway regulated $\Sigma \mathrm{UMP}$ level in cells and that the degradation pathway had little effect. Dietary pyrimidine nucleotides and bases are not utilized by other tissues since dietary uracil nucleosides are metabolized in the liver (13). On the other hand, deoxythymidine injected intravenously was utilized by cells (14). The liver becomes the origin of circulating uridine (15) and a high concentration of uridine in the medium inhibits de novo pyrimidine biosynthesis and is utilized by cultured L1210 cells (16). When cells were incubated with an inhibitor of de novo biosynthesis, the plasma concentration of uridine maintained normal cell growth (16). The increase in dihydropyrimidine dehydrogenase activity increased the pyrimidine-degradation rate in vivo (Tables 4, 5 and Fig. 2). These data show that pyrimidine nucleosides are utilized by the tissues and affect pyrimidine metabolism. Hence, it was thought that the role of the pyrimidine degradative pathway in liver was the degradation of dietary pyrimidine nucleosides, maintenance of the pyrimidine pool in the liver, and regulation of the pyrimidine nucleosides content in plasma so as not to affect pyrimidine metabolism in other tissues. However, uracil, uridine, and $\Sigma$ UMP pool did not change when dihydropyrimidine dehydrogenase decreased following administration of a vitamin $B_{2}$-deficient diet (7). The result shows that liver was able to degrade most dietary pyrimidines if the diet did not contain high level of pyrimidines. Pyrimidine nucleotide levels in lymphocytes increases with cell growth (17). There may be a difference between liver cells and lymphocytes in the 
regulation of the pyrimidine pool.

It has been reported that glucocorticoid inhibits uridine absorption (18); however, since the $\left[6-{ }^{3} \mathrm{H}\right]$ uridine and 5-fluorouridine levels in the glucocorticoid group soon after addition or administration were the same as those of the control group, it was thought that glucocorticoid did not affect uridine absorption under these conditions. The rate of consumption of 5-fluorouridine in serum increased following glucocorticoid treatment (Fig. 2). At the same time dihydropyrimidine dehydrogenase activity in liver increased but that in blood did not. Most dihydropyrimidine dehydrogenase activity was present in the liver (7). Hence, an increase in 5-fluorouridine degradation following glucocorticoid therapy was the result of an increase in dihydropyrimidine dehydrogenase activity in the liver. Thus it was thought that most 5-fluorouridine was incorporated into the liver, degraded to 5-fluorouracil and then degraded by dihydropyrimidine dehydrogenase.

\section{REFERENCES}

1) Fritzson, P. (1957): The catabolism of ${ }^{14} \mathrm{C}$-labeled uracil, dihydrouracil, and $\beta$ ureidopropionic acid in rat liver slices. J. Biol. Chem., 226, 223-228.

2) Weber, G., Queener, S. F., and Ferdinandus, A. (1970): Control of gene expression in carbohydrate, pyrimidine and DNA metabolism, in Advances in Enzyme Regulation, ed. by Weber, G., Pergamon Press, Oxford, Vol. 9, pp. 63-95.

3) Fritzson, P. (1961): The relation between uracil-catabolizing enzymes and rate of rat liver regeneration. J. Biol. Chem., 237, 150-156.

4) Iigo, M., Nishikata, K., Nakajima, Y., Hoshi, A., Okudaira, N., Odagiri, H., and De Clereq, E. (1980): Enhancing effect of bromovinyl deoxyuridine on antitumor activity of 5-deoxy-5-fluorouridine against adenocarcinoma 755 in mice. Biochem. Pharmacol., 38, $1885-1889$.

5) Tatibana, M., and Shigesada, K. (1972): Two carbamyl phosphate synthetases of mammals specific role in control of pyrimidine and urea biosynthesis, in Advances in Enzyme Regulation, ed. by Weber, G., Pergamon Press, Oxford, Vol. 10, pp. 249-271.

6) Orengo, A. (1969): Regulation of enzymatic activity by metabolites. I. Uridinecytidine kinase of Novikoff ascites rat tumor. J. Biol. Chem., 244, 2204-2209.

7) Fujimoto, S., Matsuda, K., Kikugawa, M., Kaneko, M., and Tamaki, N. (1991): Role of flavin in rat liver dihydropyrimidine dehydrogenase activity. J. Nutr. Sci. Vitaminol., 37, 89-98.

8) Naguib, F. M. N., el Kouni, M. H., and Cha, S. (1985): Enzymes of uracil catabolism in normal and neoplastic human tissues. Cancer Res., 45, 5405-5412.

9) Tamaki, N., Kaneko, K., Mizota, C., Kikugawa, M., and Fujimoto, S. (1990): Purification, characterization and inhibition of D-3-aminoisobutyrate aminotransferase from the rat liver. Eur. J. Biochem., 189, 39-45.

10) Granner, D. K., and Tomkins, G. M. (1970): Tyrosine aminotransferase (rat liver). Methods Enzymol., 17A, 633-637.

11) Tanaka, K., Sato, M., Tomita, Y., and Ichihara, A. (1978): Biochemical studies on liver functions in primary cultured hepatocytes of adult rats. J. Biochem., 84, 937-946.

12) Bronk, J. R., and Hastewell, J. G. (1988): The transport and metabolism of naturally 
occurring pyrimidine nucleosides by isolated rat jejunum. J. Physiol., 395, 349-361.

13) Sonoda, T., and Tatibana, M. (1978): Metabolic fate of pyrimidines and purines in dietary nucleic acids ingested by mice. Biochim. Biophys. Acta, 521, 55-66.

14) Killmann, S. (1964): Erythropoietic response to thymidine in pernicious anemia. Acta Med. Scand., 175, 489-497.

15) Monks, A., and Cysyk, R. L. (1982): Uridine regulation by the isolated rat liver: Perfusion with an artificial oxygen carrier. Am. J. Physiol., 242, R465-R470.

16) Karle, J. M., Anderson, L. W., and Cysyk, R. L. (1984): Effect of plasma concentrations of uridine on pyrimidine biosynthesis in cultured L1210 cells. J. Biol. Chem., 259, 67-72.

17) Marijnen, Y. M. T., De Korte, D., Haverkort, W. A., Den Breejen, E. J. S., Van Gennip, A. H., and Roos, P. (1989): Studies on the incorporation of precursors into purine and pyrimidine nucleotides via de novo and salvage pathways in normal lymphocytes and lymphoblastic cell-line cells. Biochim. Biophys. Acta, 1012, 148-155.

18) Roth, G. S. (1975): Age-related changes in glucocorticoid binding by rat splenic leukocytes: Possible cause of altered adaptive responsiveness. Fed. Proc., 34, 183-185. 